\title{
AMAR DE VERDAD LOS TEXTOS: HIBRIDACIONES FÍLMICAS EN LA ESCRITURA DE JAVIER MARÍAS
}

LOVING TRULY TEXTS: FILMIC HYBRIDIZATIONS IN JAVIER MARÍAS'

WRITING

CaRmen María López LóPez

Universidad de Murcia /

Universidad Católica San Antonio de Murcia

cmlopez@ucam.edu

ResUmen: Partiendo de la premisa metodológica de la traducción intersemiótica de Jakobson (1959), este estudio aspira a diseñar un marco teórico acerca de las estrategias del lenguaje fílmico en la escritura de Javier Marías. Un punto clave común a todas ellos es la condición inherente de lo cinematográfico. Esto significa que, en contraste con otros documentos visuales (fotografías, mapas o cuadros), reproducidos por Marías en las novelas, el cine se integra en una dimensión verbal, mediante la palabra. En síntesis, este estudio distingue diversos criterios (verbalización, superposición y pluralidad) acerca de los mecanismos fílmicos, ofreciendo un aspecto de su obra que todavía no ha sido tenido en consideración por la crítica especializada.

PaLABRAS CLAVE: Javier Marías, narrativa española contemporánea, lenguaje fílmiCo, teoría literaria, traducción intersemiótica

ABSTRACT: Starting from the methodologic premise of Jakobson's intersemiotic translation (1959), this study aims at designing a theorethical framework about the procedures of filmic language in Javier Marías' writing. A common key point that embrace all of these is the inherent condition of cinema. It means that, in contrast with other visual documents (photographs, maps or paintings), included by Marías in novels, cinema is integrated on a verbal dimension, by words. In synthesis, this study distinguishes several criteria (verbalization, superposition and plurality) about filmic mechanisms in his work which have not been taken into consideration by the specialised critics. 
KeyWords: Javier Marías, Contemporary Spanish Novel, Filmic Language, Literary Theory, Intersemiotic Translation

\section{toter}

\section{JaVier Marías y el CINE: NOtAS INTROdUctorias}

El hispanismo actual viene atravesando una época de floreciente resurgir de la imagen (pictórica, fotográfica, fílmica, etc.) y, de entre ellas, destaca la recuperación de los estudios narrativos a la luz de sus imbricaciones con el lenguaje del cine. Esta doble discursividad verbal y visual invita a redefinir el concepto de texto porque, en palabras de Genette, "si se aman de verdad los textos, se debe desear, de cuando en cuando, amar (al menos) dos a la vez" (1989: 42).

La escritura de Javier Marías inscribe su pensamiento estético en esta dinámica conceptual, revistiendo así un problema teórico que afecta a la relación de su obra con las distintas menciones explícitas, alusiones y referencias veladas al Séptimo Arte. Conscientes de esta problemática, el hibridismo que aquí se explora puede apreciarse ya en el célebre artículo "Cabezas llenas" (Marías 1993: 427) recogido en Literatura y fantasma, donde Javier Marías reflexionó sobre la singularidad de los artistas, según los instrumentos y cauces expresivos afines a su creación.

A juicio de Marías, mientras que los pintores tienen la cabeza llena de "imágenes, volúmenes y colores", la cabeza de los músicos está adornada de "notas" y "melodías", así como la de los escritores atesora "principalmente palabras". Esta manera de deslindar con tanta lucidez los ámbitos de creación en distintas artes, según distintos códigos semióticos (verbales, visuales y auditivos), supone el punto de inicio de nuevas formas de hibridación, pues como sostiene Marías, aunque la cabeza de los escritores alberga las palabras -la verbalización como molde expresivo- también está llena también "de imágenes, de historias, de argumentos, de personajes, de diálogos, de escenarios, de rimas" (Marías 1993: 427). Como se deduce de las ideas expuestas en este ensayo, el escritor otorga importancia no solo a las palabras - cauce verbal- sino a las imágenes -cauce visual-como impulso de su escritura.

Afianzado en la idea de que ser espectador constituye la clave de todo ejercicio intelectual -mirar largamente las cosas para, a fortiori, pensar sobre ellas-, la cabeza del escritor concede un lugar privilegiado a las estrategias visuales, sobre todo de índole cinematográfica. Ya desde su primera novela (Los dominios del lobo, 1971), el motor creativo de su obra se encuentra en "ochenta y cinco películas norteamericanas consumidas por Marías durante una breve estancia en París" (Steenmeijer 2001: 7). De manera concreta, el escritor ha reflexionado sobre la impronta cinematográfica de sus novelas. Como expresó Marías en el compendio de artículos sobre cine titulado Donde todo ha sucedido. Al salir del cine (2005), "también es raro que no haya en ellas [mis novelas] alguna esce- 
na o pasaje que, calladamente, no sea deudor de algo contemplado en la oscuridad de una sala y retenido en la memoria para siempre jamás" (Marías 2005: 30).

Puesto que el cine constituye una clave cultural y hermenéutica en la escritura de Marías, sobre la presencia del Séptimo Arte en su narrativa conviene recordar las palabras de Deza, narrador del ciclo de Oxford, ${ }_{1}^{1}$ cuando atribuye a su discurso la condición de un legado cinematográfico, como si hubiera escuchado todas sus palabras en el cine, conformando así un nudo indisociable entre la vida y la experiencia estética cinematográfica:

Todas estas frases que hemos visto pronunciar en el cine las he dicho yo o me las han soltado o se las he oído a otros a lo largo de mi existencia, esto es, en la vida, que guarda mucha más relación con las películas y la literatura de lo que se reconoce normalmente y se cree. (Marías 2013c: 29-30)

Según expresa Deza, la construcción de un mundo ficticio en la obra de Marías viene vertebrada por un entramado de códigos sígnicos que convergen en su escritura. Es así como el cine deviene "clave cultural y hermenéutica" (López López 2015: 287) de su escritura.

Espectador fiel a la cinematografía clásica del Hollywood de los años cuarenta y cincuenta, el universo narrativo de Javier Marías se enriquece a la luz de distintas claves fílmicas: Vértigo (1958) de Alfred Hitchcock, Recuerdo de una noche (1940) de Mitchell Leisen, El fantasma y la señora Muir (1947) de Joseph L. Mankiewicz, El río de Jean Renoir y Campanadas a medianoche (1965) de Orson Welles.

Pese a la singularidad de las estéticas cinematográficas de cada uno de estos directores, el índice de coherencia del corpus de películas se mide por su pertenencia a cinematografías afines al gusto estético del novelista, según manifiesta en sus ensayos sobre cine (2005), al ser obras concentradas en un arco temporal concreto (1940-1965): Recuerdo de una noche, primera película a la que se hace mención, de 1940, y Campanadas a medianoche, de 1965, con que se cierra el corpus filmográfico. Destaca el cine de las décadas de los cuarenta, cincuenta y sesenta, con el gran florecimiento durante la época dorada de Hollywood, pero también cinematografías europeas como la de Jean Renoir y Laurence Olivier, así como con proyectos cuyo rodaje se llevó a cabo en España, como es el caso de Campanadas a medianoche de Orson Welles

A la luz de este entramado fílmico, la escritura mariesca orbita en torno a una fenomenología visual, en el cruce de experiencias externas que el suje-

\footnotetext{
${ }^{1}$ Ciclo de Oxford es el rótulo que engloba Todas las almas (1989), Negra espalda del tiempo (1998) y Tu rostro mañana (2002-2007), esta última compuesta a su vez de sucesivas entregas -Tu rostro mañana 1. Fiebre y lanza (2002), Tu rostro mañana 2. Baile y sueño (2005) y Tu rostro mañana 3. Veneno y sombra y adiós (2007), denominación surgida antes con una voluntad editorial que, con un propósito inherente a lo literario, en la edición de 2013 en De Bolsillo. No obstante, en Figuraciones del yo en la narrativa. Javier Marías y Enrique Vila-Matas (2010), Pozuelo Yvancos se anticipó al referirse a él como "ciclo Deza" (2010: 11), si bien ha sido ciclo de Oxford la nomenclatura que ha cuajado al permitir la inclusión de Negra espalda del tiempo pese a que Deza no aparezca en ella ni como narrador ni como personaje. En la actualidad la crítica (Scharm 2013; Pozuelo Yvancos 2017) suele referirse a estas novelas bajo la condición de ciclo.
} 
to contempla o escucha, bien sea de manera premeditada o furtiva, aludiendo constantemente a imágenes del cine (López López 2019). En este sentido, el despliegue narrativo de una superposición de imágenes, según explicó Heike Scharm, conecta "las reflexiones de Deza de Tu rostro mañana con las del narrador de El siglo, el de Todas las almas, el auto-narrador de Negra espalda del tiempo, y hasta más allá de la obra de Marías, evocando e incorporando escenas e imágenes de otras obras (cine, literatura, música, arte visual)" (Scharm 2013: 100). Por ello, a lo largo de estas páginas se tratarán de dilucidar las claves de una poética fílmica como clave sustancial en la escritura de Javier Marías.

\section{LA POÉTICA FÍlMICA de JAVIER MARÍAS DESDE LA TRADUCCIÓN INTERSEMIÓTICA}

A la luz de estas ideas, con el fin de indagar las posibilidades sígnicas y confluencia entre lenguajes, la teoría de la traducción de Jakobson constituye un primer soporte interpretativo. En su emblemático artículo "On Linguistic Aspects of Translation", publicado en 1959 si bien incluido en los años ochenta en sus Ensayos de lingüística general en el capítulo "En torno a los aspectos lingüístico de la traducción", Roman Jakobson distinguió una tríada conceptual en la que sistematiza los tres tipos fundamentales de traducción: intralingüística (reformulación por medio de signos pertenecientes a la misma lengua); interlingüística (traducción entre lenguas distintas); e intersemiótica (transmutación e interpretación de los signos verbales de un texto mediante signos de otro sistema de codificación semiótica: musical, cinematográfico, pictórico, etc.).

Centrándonos en esta última, de especial relieve para indagar el modo en que los códigos verbales interactúan con signos audiovisuales, propios del cine, la traducción intersemiótica conforma un estadio explicativo de las relaciones verbo-visuales en la narrativa de Javier Marías, en el continuo cruce e hibridez "del arte de la palabra a la música, la danza, el cine o la pintura" (Jakobson 1981: 77).

Lejos de toda abstracción teórica, en The Fictional World of Javier Marías. Language and Uncertainty, Pérez-Carbonell (2016) se hizo eco de los tres tipos de traducción distinguidos por Jakobson, con el fin de articular una reflexión sobre las posibilidades traductológicas en la narrativa de Javier Marías. Este estudio pionero en que se cruzan semiótica y traducción se sitúa como pórtico de nuestra investigación. Sin embargo, si bien Pérez-Carbonell abordó los tres tipos de traducción aducidos por Jakobson, este estudio explorará las posibilidades de la traducción intersemiótica -entre distintos sistemas de codificación sígnica-, de gran relieve para vincular cine y literatura en su obra.

A modo de ejemplo para ilustrar el enfoque de Pérez-Carbonell, en su estudio da cuenta de casos de traducción intersemiótica en Corazón tan blanco, como el vídeo que Berta y Juan ven en Nueva York y el cuadro Artemisa (1634) de Rembrandt que Juan y Mateu contemplan en el Museo del Prado (2016: 57). Estos tipos de traducción insermiótica vienen signados por la imposibilidad de encontrar un eje seguro a causa de la falta del código visual, esto es, la ausencia 
de asideros estables de la fuente textual al traducir un mensaje no lingüístico -de naturaleza visual- como lingüístico.

En la escritura de Javier Marías, el cine como Séptimo Arte es la máquina creadora de imágenes en movimiento, fotogramas cuyo poder visual es asimilado a la ficción narrativa. Integrada en el tejido verbal, la imagen fílmica se concibe como plasmación verbal de una representación visual. Su narrativa no se sustenta sobre un doble código (verbal y visual), como sucede con la reproducción de mapas, fotos o cuadros pictóricos. Las imágenes y planos fílmicos se evocan verbalmente y generan discurso. En este sentido, la materia fílmica incentiva el discurso mental, aviva los cauces del pensamiento, desplegándose como fuente discursiva si bien pasada por el tamiz de la vivencia personal y emotiva del personaje ficticio que la piensa, quien la rescata de su contexto para traducirla mediante una asociación a su experiencia vivida. Desplazada mediante una traslación metafórica o metonímica del contexto de origen (el de la película desde donde se irradió) al contexto meta (la obra narrativa en que ahora se inserta), la imagen fílmica se somete a un proceso de traducción e interpretación según la experiencia subjetiva del personaje.

Si traducir es, en sentido etimológico ("trans-ducere", pasar de un lado a otro), trasladar, transferir, es decir, guiar y dirigir, al mismo tiempo enhebra el matiz de la traición inherente a todo proceso traductológico (la célebre sentencia traduttore, traditore de Umberto Eco es reveladora en este punto). El concepto de la traducción intersemiótica se inserta en esta misma filiación etimológica, englobada en un marco de relaciones comunicativas entre lenguajes.

Desde distintas perspectivas críticas (Logie 2001; Pérez-Carbonell 2016, 2017), se ha puesto de relieve la importancia de la traducción en las novelas de Javier Marías. En su estudio "La traducción, emblema de la obra de Javier Marías", Ilse Logie (2001: 72) fue consciente de ese proceso de "traducción intersemiótica" en su narrativa, por cuanto los textos escritos se transfieren hermenéuticamente a otros medios como el cine. Desde un enfoque lingüístico y traductológico, Pérez-Carbonell (2017: 339) esgrimió, como hemos visto, muy sólidos argumentos -a partir de los tres tipos de traducción propuestos por Jakobson-, para caracterizar a los narradores en las novelas de Marías como "traductores compulsivos" (compulsive translators).

Aunque dentro de un marco intrasemiótico, en las páginas iniciales de Negra espalda del tiempo el narrador innominado da buena cuenta de esta dificultad de contar y muestra -sin ambages- su particular escepticismo: "Así, cualquiera cuenta una anécdota de lo que ha sucedido y por el mero hecho de contarlo ya lo está deformando y tergiversando, la lengua no puede reproducir los hechos ni por lo tanto debería intentarlo" (Marías 2013a: 7). De este modo se inserta una reflexión central acerca de los escollos de la lengua para expresar exactamente aquello que uno quiere decir, pues escribir es traducir, hecho del que se deriva que la complejidad de los fenómenos de traducción o transducción se incremente cuando se estudian y emparentan distintos códigos semióticos. En el artículo "Asuntos translaticios" de Literatura y fantasma (1993), Javier Marías ahonda nuevamente en los procesos de la traducción. Es por ello que la 
traducción "simboliza el principio de mediación que rige tanto la vida como la literatura, tanto la creación como la recreación. Aspirando a la identidad, halla su razón de ser en la diferencia y en la distancia, y ejemplifica de este modo el funcionamiento de cualquier proceso de interpretación" (Logie 2001: 75).

En el trasvase de carácter semiótico entre códigos, la fidelidad en la transposición del texto literario al medio fílmico ha actuado como concepto vertebral en torno al cual se articulaba la dinámica de las relaciones entre novela y cine, según atestiguan las clásicas monografías especializadas en el tema (Gimferrer 1985; Utrera 1985; Company 1987; Peña-Ardid 1992). Toda aproximación crítica que excediera este paradigma y se desviara por otros derroteros era denostada por considerarse una infidelidad execrable. Este ha sido el principal escollo de la adaptación literaria, así como de los enfoques tradicionales sobre las relaciones entre texto literario y texto fílmico. Prevalece, por tanto, la idea de que "la transposición como traición, como si el pasaje del texto literario a la pantalla fuera siempre el resultado de la calculada perfidia que el cine inflige a la literatura. Una perfidia que solo busca reducir los alcances del libro, jibarizarlo o despojarlo" (Wolf 2001: 30).

Sánchez Noriega (2000: 63-75), consciente de este problema en torno a la dialéctica fidelidad/traición (creatividad) entre los dos textos fílmico-literarios, ofreció una tipología clasificatoria en la que es preciso advertir una gradación que se articula progresivamente desde el grado máximo de dependencia del texto fílmico al literario, pasando por la transposición e interpretación más o menos libre, para llegar a la adaptación libre que apenas se acoge a las características de la obra original. En este sentido, su propuesta permite ahondar en adaptaciones veladas, en las que asistimos a una transcodificación apenas perceptible, invisible o subyacente.

En una línea de gran interés para nuestro estudio, Wolf (2001: 89-157) propuso nuevas formas de transposición fílmico-literaria a partir de lo que denomina "fidelidad insignificante", para ahondar en las posibilidades de un "texto reinventado" o de una "versión no declarada" (Wolf 2001: 89-157). Asimismo, Faro Forteza (2006: 117-356) estableció una distancia entre lo que denomina "adaptación iteracional" (pura, por transición o por reducción) y "adaptación libre" (por motivo, por conversión y por ampliación), estableciendo una distancia entre la adaptación fidedigna frente a la libre que se permite un mayor número de licencias creativas.

Desde estas consideraciones, se contempla un nuevo horizonte para abordar el diálogo fílmico-literario, sustentado sobre nuevas concepciones de procesos intersemióticos, a raíz de la superación del modelo crítico que consideraba la validez artística de la obra cinematográfica en términos de fidelidad respecto al texto base:

Utilizar como criterio de evaluación de los filmes nacidos de textos literarios la "fidelidad" o la "infidelidad" del producto visual respecto de su materia prima verbal supone menospreciar la potestad de la imagen cinemática, plástica e icónica, para reemplazar la designación (lingüística) por la exhibición (epifáni- 
ca), y el lenguaje (disociativo, analítico) por la para-simbolia (asociativa, sintéti-

ca). (González de Ávila 2010b: 110)

\section{EL LUGAR DE LAS IMÁGENES: ENSAYO DE CLASIFICACIÓN}

Tratar de establecer o sintetizar los parámetros que, a la luz de esta discusión teórica, configuran el tratamiento de lo fílmico en la narrativa de Javier Marías resulta muy complejo, sobre todo por las formas tan diversas en que el novelista asimila la materia fílmica en su obra. No obstante, se pretenden perfilar algunos principios generales conformados como ejes o calas hermenéuticas acerca del horizonte cinematográfico en Marías. Todos estos parámetros que se van a deslindar a efectos metodológicos, se cruzan y responden a un interés común: la imagen fílmica genera discurso, esto es, propicia el devenir mental del personaje.

En tanto que "la mirada como generadora de discurso constituye el núcleo argumental de las novelas de Javier Marías" (García de León 2004: 223), el cine se alza como cauce de expresión del pensamiento, matriz visual que incide en la conformación de su escritura. Si la creación artística se instaura en las novelas de Marías como "vía alternativa al conocimiento" (Scharm 2013: 18), el componente visual de sus novelas se acentúa a partir de la materia fílmica. En virtud de que la imagen fílmica genera discurso, cognición y percepción, pensamiento y estímulos sensoriales se integran en su escritura.

¿Qué tipos de imágenes cinematográficas son y cómo funcionan en el marco de la textualidad? Como bien ha expresado González de Ávila (2010a: 228232), la tipología más sencilla de imágenes es aquella que las clasifica en imágenes perceptivas (o naturales) provenientes de los sentidos o de la experiencia sensorial; imágenes mentales, producto de la actividad cognitiva en tanto que representación mental de una imagen visual; e imágenes técnicas o artificiales, provenientes de distintos soportes (papel, lienzo, pantalla cinematográfica, etc.).

Aunque el modelo triádico presenta solidez suficiente, lo común en el funcionamiento operativo de las imágenes es que estos tipos interactúen de manera dinámica. A diferencia de la imagen mental que únicamente requiere del "trabajo neurofisiológico del cerebro" (González de Ávila 2010a: 228), la imagen artificial o técnica precisa de un médium -el lienzo de un cuadro, la pantalla de televisión- para plasmarse como experiencia visual. De este modo, frente al iconismo primario de las imágenes perceptivas y mentales, las imágenes artificiales o técnicas se caracterizan por su iconismo secundario, en tanto que reclaman un medio - pinturas, dibujos, fotografías, pantalla cinematográfica- para dotarse de materialidad (González de Ávila 2010a: 234).

Pese a sus singularidades, en la escritura de Javier Marías dialogan distintos tipos de imágenes, interacción derivada del quiebro del dualismo entre cognición y percepción. De hecho, "cualquier imagen "perceptiva" o "técnica" lo es también "mental", dado que se procesa en las redes neuronales y no solo en los órganos de los sentidos" (González de Ávila 2010a: 228). De este modo, la distinción entre imágenes interiores o endógenas y exteriores o exógenas se 
considera una posición obsoleta que no logra sino perpetuar la antítesis entre espíritu y materia.

Consideramos, por tanto, que esta tipología triádica sobre las imágenes, lejos de ser reduccionista, resulta abarcadora e interactiva. Además, las imágenes perceptivas se procesan mentalmente, lo que invita a cuestionar la dicotomía entre imágenes interiores y exteriores: "separar radicalmente el pensamiento visual y lingüístico-proposicional, a pesar de los rasgos diferenciales de uno y otro, nos parece improductivo en el plano del conocimiento científico" (González de Ávila 2010a: 230). Los estímulos visuales captados a través de la percepción sensorial se integran en un umbral superior: la mente o aparato cognitivo donde se procesan, de ahí que sea erróneo separar percepción y cognición, imágenes perceptivas e imágenes mentales (Belting 2012: 26).

De manera concreta, la expresión "los ojos de la mente" (Marías 2013c: 320) explicitada en la narrativa de Marías orbita en esta esfera acerca de la imposible separación entre percepción (ojo) y cognición (mente), así como el marbete de mindscreen (Kawin 1978), para referirse a su vez a los ojos de la mente, es decir, las imágenes mentales fraguadas mentalmente por el personaje. Desde estas coordenadas, la narrativa de Marías integra distintos tipos de imágenes -perceptivas, mentales y artificiales-, si bien cruzan sus motivaciones. En esta línea en que estamos indagando, las imágenes perceptivas o naturales de Clare Bayes, el niño Eric y su padre que el narrador visualiza externamente en el museo arqueológico de Oxford en Todas las almas, asimiladas a la materia fílmica de Vértigo (Hitchcock, 1958), pasan por un procesamiento mental desencadenante del discurso interior del narrador.

Al igual que las imágenes perceptivas o naturales se hacen eco de su trasunto mental al asimilar la materia fílmica a la experiencia íntima del sujeto -en los pasajes de inspiración hitchcockiana en Todas las almas, Tu rostro mañana o Así empieza lo malo-, las imágenes artificiales o técnicas vistas en la pantalla televisiva en que se emiten las películas de Mitchell Leisen (Recuerdo de una noche) o de Orson Welles (Campanadas a medianoche), encuentran en Mañana en la batalla piensa en mí su ejemplo más logrado (López López 2018). Scarlett ${ }^{2}$ (2004: 392) estudió cómo las imágenes artificiales que Víctor Francés y Marta Téllez contemplan en la pantalla de televisión la noche funesta en que muere Marta, quedan grabadas en su imaginario vital, en un procesamiento mental de la materia fílmica asimilada a la vivencia, por lo que de nuevo se aprecia el vínculo indeleble entre lo percibido y lo pensado, el predominio del "pensamiento visual" (Arnheim 1986; Martín-Estudillo 2009).

En síntesis, imágenes perceptivas, mentales y técnicas se entrecruzan para responder a un mismo afán: la necesidad incesante de interpretar el mundo. En

2 El artículo de Scarlett bajo el título "Victors, Villains and Ghosts: Filmic Intertextuality in Javier Marías's Mañana en la batalla piensa en mí", y publicado en Revista Canadiense de Estudios Hispánicos, aborda la intertextualidad fílmica en la citada novela. Si bien de manera incipiente y aún con leves menciones a las películas que conforman esta obra de ficción, Scarlett inicia una línea de estudios analíticos sobre la presencia del cine en la narrativa de Marías, esta vez articulada a partir de intertextos que la autora identifica en virtud de las pruebas textuales constatables en la novela. 
las novelas de Javier Marías, los personajes acogen estímulos visuales de naturaleza cinematográfica, piensan el cine y lo ven en la pantalla, ofreciendo un arco de posibilidades tan estimulante como sugestivo.

\subsection{Verbalización: de la pluralidad sígnica al estatuto verbal de la imagen}

El problema de relacionar palabra e imagen -textos verbales y visuales- es casi tan antiguo como la humanidad misma, si bien solo de manera tardía se ha tratado de sistematizar a partir de un marco teórico coherente que muchas veces excede su propia delimitación. Dar cuenta de esta problemática con detenimiento y exhaustividad no solo desbordaría el propósito de este estudio, sino que apenas nada nuevo podría aportar más que un acopio de datos y fuentes bibliográficas a las que se remite al lector (Hefferman 1993; Wagner 1996; Pimentel 2003; Agudelo 2011). Más relevante que volver a los lugares ya fijados de esta relación resulta reflexionar acerca del modo en que Marías integra en su obra la materia fílmica. ¿Desde qué lugar mira e interpreta Javier Marías el cine? ¿Cómo se integra en sus novelas? ¿Qué procedimientos y estrategias acoge?

El tratamiento de lo fílmico en la narrativa de Marías excede los estrechos límites de la écfrasis (Hefferman 1993; Wagner 1996). Como venimos comentando, las novelas no representan ni describen verbalmente escenas fílmicas: las integran en el relato hasta devenir fabulación, imaginación, pura inventiva. En este sentido, la materia fílmica se integra como una operación referencial, verbalizada a través de la escritura. Esta problemática de imbricar texto e imagen o de hablar de visualidad del texto literario remite al Laocoonte (1776) de Lessing, quien prefiere adoptar una posición purista y delimitar de manera rigurosa las formas de expresión de cada una de las artes (verbales y visuales), en concreto de la literatura y la pintura:

La pintura y la poesía deberían ser igual que dos vecinos que se llevan muy bien, ninguno de los cuales puede parecer tomarse libertades en el campo del otro, sino que ejercitan un respeto mutuo de sus fronteras y llegan a un acuerdo pacífico respecto a todos esos pequeños asaltos que las circunstancias pueden forzar a cualquiera de los dos a ejercer sobre los derechos del otro. (Lessing 1985: 110)

Las palabras de Lessing responden a un sentido clásico de la purificación de la pintura y su cautela para no invadir el dominio de otras artes, posición muy legítima si bien se quiebra ante las posibilidades para integrar la imagen en una novela, ya sea expuesta visualmente o representada verbalmente. Al quebrarse la idea clásica de Lessing sobre la purificación de las artes, el texto literario deviene no solo una construcción semántica sino también un dispositivo integrador de fuentes visuales y sensoriales que impregnan el tejido verbal.

Contra las ideas del autor del Laocoonte reaccionan de manera radical los estudios visuales (visual studies), pues no consideran que la pintura y la poesía -por extensión, la literatura y otras artes- deban mantener su especificidad y no incluir aspectos de disciplinas artísticas que, según la tradición, les son ajenas. Al 
carecer de un centro de seguridad epistémico, el dominio del arte se disgrega en múltiples direcciones y gana, en cambio, un valioso hibridismo que lo renueva: la literatura se alimenta de la visualidad de artes como el cine; el cine deviene pura narrativa; la pintura acoge modelos y perspectivas de la arquitectura, etc. Desde esta mirada, ha emergido una lucha contra la "purificación utópica del lenguaje" (Mitchell 2009: 89), hacia el hibridismo y cruce entre disciplinas que integran en una sola distintos objetos artísticos.

Centrándonos en los enfoques actuales - provenientes en su mayoría de los estudios visuales-, las conjunciones visuales/verbales se pueden abordar desde dos ángulos diferentes: por un lado, desde el lenguaje y la literatura; por otro, desde el ámbito de la representación visual. La segunda opción que ofrece Mitchell (2009), aunque no nos interesa para nuestro estudio, es la de los "textos pictoriales", en la que el lenguaje queda reprimido en el campo visual. En el primer caso, mucho más revelador para pensar las articulaciones entre palabra e imagen, se trata de "imágenes textuales", es decir, "la evocación de la imagen visual como la sede de la diferencia dentro del lenguaje" (2009: 45). En esta primera posibilidad teórica, mucho más sugestiva para los estudios literarios, la imagen visual es evocada y convocada mediante la palabra y a partir de ahí se crea una "diferencia", en sentido derrideano, en tanto que las grietas de la imagen introducen una aporía en la significación. Lejos de acercarse a los perfiles de la écfrasis o descriptio en la narrativa, son códigos en disputa integrados verbalmente, en una imagen-plano como construcción imaginaria evocada simbólicamente por los monologadores en las novelas de Marías.

De este modo se establecen vasos comunicantes entre discurso verbal e imagen fílmica que superan el rígido marco de las comparaciones, sustentado tradicionalmente sobre la base de las homologías formales o analogías estructurales. Las "imágenes textuales" centran su horizonte en la visualidad del lenguaje, esto es, en "la representación verbal de la representación visual" (Mitchell 2009: 101). Los interrogantes que las "imágenes textuales" plantean a Mitchell son los siguientes: "¿qué es lo que motiva el deseo de construir todo un texto como una evocación, incorporación o sustituto de un objeto o una experiencia visual? ¿Por qué parece que los textos se ven impulsados a alcanzar su "otro" semiótico, los objetos de representación visual?" (Mitchell 2009: 101).

Pese a los interrogantes de Mitchell, en la relación cine-literatura en la narrativa de Marías no hay dos códigos o sistemas (verbal y visual). Como pudo apreciarse, Pérez-Carbonell (2016) ya advirtió que la ausencia del código visual dificulta los procesos de traducción intersemiótica, en virtud de la falta del elemento visual suplido por el discurso verbal que -al nombrarlo- lo convoca. ${ }^{3}$ Estos tipos de traducción insermiótica vienen signados por la imposibilidad de hallar un eje seguro a causa de la falta del código visual, esto es, la ausencia de asideros estables de la fuente textual al traducir un mensaje no lingüístico como lingüístico.

3 Ilustran esta idea los ya citados casos de traducción intersemiótica en Corazón tan blanco: el vídeo que Berta y Juan ven en Nueva York y el cuadro Artemisa (1634) de Rembrandt que Juan y Mateu contemplan en el Museo del Prado. 
A diferencia de lo que sucede con las fotos o cuadros pictóricos reproducidos en sus novelas, el cine se integra en el tejido verbal como una operación referencial, puesta en palabras, a modo de "imágenes textuales" (Mitchell 2009: 101), es decir, como representación verbal de una imagen visual. La singularidad de la materia fílmica en la narrativa de Marías estriba en que no se inserta de manera icónica reproduciendo fotogramas como cuadros visuales, tal como sí sucede con las fotografías o los cuadros pictóricos. He aquí la especificidad y el tratamiento original que Marías otorga al discurso cinematográfico, ofrecido verbalmente en una ausencia de codificación doble de la que sí gozan la fotografía o la pintura como procedimientos intermediales en la narrativa del escritor. Esta situación contrasta, como ya anunciábamos, con las fotografías y los cuadros pictóricos insertos en sus novelas, de los que ofrecemos una somera síntesis para distinguir cómo operan las estrategias pictóricas y fotográficas en sus obras frente a las fílmicas.

Esta idea se explicita al constatar la proliferación de documentos visuales en su obra, conformadores de un doble sistema de representación por la vía de lo verbal y lo visual integrado en la escritura. En este sentido, cuando las imágenes inundan una novela, el análisis de la misma deviene poliédrico en la interacción de códigos de distinta naturaleza, en esencia verbal y visual. Si bien la novela es un texto hecho de palabras, Marías incluye en sus obras -de modo fundamental en el conjunto coherente del ciclo de Oxford-distintos dispositivos visuales (retratos de familia, carteles de guerra, cuadros pictóricos, etc.).

Desde distintos ángulos la crítica se ha hecho eco de esta doble codificación sígnica al abordar la escritura de Marías como interrelación de lenguajes. De acuerdo con esta idea, Miller (2004: 97-110) incidió en el diálogo gráfico-léxico presente en su obra, a partir de la inserción de fotografías en Todas las almas, Negra espalda del tiempo y Tu rostro mañana. De manera concreta, la aproximación de Antonio Candeloro (2008: 58) a los "documentos visuales" (fotografías, retratos, mapas de Redonda) en Negra espalda del tiempo vincula la escritura de Marías en la tradición novelística europea de autores como W. G. Sebald, por su tendencia a insertar fuentes visuales en las páginas de la novela. Esta línea interpretativa a partir del archivo visual de la escritura se proyecta en asedios críticos recientes, como el sagaz estudio de Elide Pittarello (2017: 353-366) a propósito de los retratos de familia reproducidos en Negra espalda del tiempo.

A partir de la llamada por Charles Forceville "metáfora multimodal", esto es, un dispositivo donde al menos se representan dos sistemas de signos, uno de carácter verbal y otro de índole visual, Pittarello (2017: 358) se centra en el motivo del retrato familiar para abordar el doble sistema de signos y su interrelación. La metáfora multimodal que, según analizó Pittarello, impregna el funcionamiento de las fotografías y retratos reproducidos en las novelas de Marías, convoca dos sistemas de signos. Texto y retrato interactúan de un modo singular. En contraste con este funcionamiento de la imagen fotográfica, la visualidad fílmica se integra en el texto, lo que genera una ausencia de iconicidad en términos de representación dual: al faltar un término A-B de la metáfora, la ausencia se desplaza metonímicamente hacia la integración de lo fílmico en el tejido verbal. 
En este sucinto recorrido por los documentos visuales insertos en las novelas, Tu rostro mañana -la tercera entrega del ciclo de Oxford-se instaura como ejemplo monumental de esta doble dimensión verbal y visual de los lenguajes en la poética de Marías. La inclusión de cuadros pictóricos y otros elementos visuales (fotografías, como la de Jayne Mansfield y Sofía Loren, lienzos pictóricos y carteles de guerra fundamentalmente de la Segunda Guerra Mundial) afianza la singularidad indiscutible de su narrativa al ofrecer no solo una reflexión verbal sobre las imágenes sino la mostración directa y contrastable de lo visual con el otro código escrito.

En otras palabras, Marías no solo habla de imágenes, sino que las enseña, haciendo partícipe al lector de su condición de espectador o, más bien, de lectoespectador, si acogemos la terminología de Vicente Luis Mora (2012). Este nuevo lector que mira, ve y contrasta lo visible con lo legible dota a la relación entre literatura y pintura de un estatuto interdiscursivo o multimodal. La interdiscurisividad nombrada así por Cesare Segre (1985) ofrece un sugestivo diálogo entre discursos pertenecientes a distintos sistemas artísticos, en una línea de estudio donde los análisis de Elide Pittarello (2017: 353-366), esta vez a propósito de los retratos de familia en Negra espalda del tiempo, trazan un camino inaugural.

Mientras que en Negra espalda del tiempo la visualidad del retrato impregna el tejido novelesco, en Tu rostro mañana (Veneno, sombra y adiós) es notable el amplio muestrario de imágenes del arte, lienzos de distinta temática que, reproducidos a lo largo de la obra, se integran como elementos visuales que otorgan un sesgo creativo a su escritura: Camilla Gonzaga, condesa de San Segundo, y sus hijos, cuadro del pintor italiano manierista Girolamo Francesco María Mazzola, mejor conocido como Parmigianino; Las edades y la muerte del pintor renacentista alemán Hans Baldung Grien; Fusilamiento de Torrijos y sus compañeros en las playas de Málaga, del pintor español a caballo entre el romanticismo y el realismo Antonio Gisbert.

Con todo, aunque pudiera pensarse que la doble codificación verbal y visual se limita a la escritura de ficción, al marco de las novelas, su latido se extiende a otras obras de no ficción o de naturaleza ensayística. Esta estrategia es visible en Vidas escritas, donde las biografías episódicas del autor se acompañan de fotografías, creando un doble código que integra elementos verbales y visuales. Otro ejemplo de este fenómeno dual en textos de no ficción se encuentra en Miramientos, donde lo visual justifica la existencia de lo verbal. El lector transita de la fotografía al texto verbal que la describe, que a su vez incita a regresar a la fotografía, retroalimentándose. Como ha estudiado López-Gay (2013: 152), la obra invita a establecer "una puesta en diálogo dinámica del lenguaje verbal y la reproducción visual". A ellas se suman otras obras de no ficción de Marías que integran elementos gráfico-léxicos (Miller 2004) o se configuran como archivo textovisual (López-Gay 2013): Literatura y fantasma (1993), Vida del fantasma $(1995,2001)$ y Salvajes y sentimentales. Letras de fútbol (2000).

La proliferación de documentos visuales en la narrativa hispánica del siglo XXI ha motivado el concepto de lo textovisual, acuñado por Vicente Luis Mora en su ensayo El lectoespectador (2012). Con él designa ciertas obras literarias donde 
lenguaje verbal e imagen coexisten en un doble código. Sin embargo, Marías se distancia de la lógica posmoderna y de las últimas narrativas transmediales para integrar lo fílmico -la imagen- en la escritura, a partir del criterio de un único código verbal. La singularidad de su escritura radica en la "articulación de huellas visuales y verbales" provenientes del archivo personal del autor (López-Gay 2013: 88). La mirada fenomenológica -anterior a la lectura- capta, registra el mundo y lo vuelca en palabras. Frente a la tentativa de los estudios de literatura en los nuevos medios en su afán por invertir la jerarquía entre palabra e imagen, la narrativa de Marías no sustituye el poder de la palabra por el de la imagen, sino que piensa la imagen a través de palabras, mediante articulaciones verbovisuales.

La ausencia del elemento icónico se suple, por tanto, con su inserción en el discurso verbal. Si la visualidad se integra en el discurso literario, a modo de representación verbal de una imagen visual, carece de sentido dirimir el estatuto de la literatura y el cine en términos jerárquicos. Sobre la menor calidad del texto fílmico frente al texto literario como opinión generalizada, se defiende Bazin al hablar del concepto de "cine impuro" (2006: 102), es decir, aquella adaptación cuya riqueza intersemiótica radique no en la copia exacta de los elementos que están en su base creativa, sino en las "impurezas" o novedades estéticas y estilísticas que configuran la nueva forma:

El cineasta no se contenta ya con plagiar, [...] se propone transcribir para la pantalla, en una quasi-identidad, una obra de la que reconoce a priori su trascendencia. ¿Y cómo podría ser de otra manera si esta obra revela una forma tan sutil de literatura que los héroes y la significación de sus actos dependen íntimamente del estilo del escritor, si los personajes están encerrados en un microcosmo cuyas leyes, rigurosamente necesarias, no tienen valor en el exterior; si la novela ha renunciado a la simplificación épica - punto de partida de los mitos-, para ser la reunión de sutiles interferencias entre el estilo, la psicología, la moral o la metafísica? (Bazin 2006: 102)

Si adaptar "ya no es traicionar, sino respetar" (Bazin 2006: 120), nuestra propuesta en un nuevo paradigma intersemiótico ofrece una mirada en la que fidelidad no signifique calco sino "íntima intelección de sus propias estructuras estéticas" (Bazin 2006: 120). En una línea de fuerza similar, aunque desde una poética fílmica más reciente, se sitúan los posicionamientos de Sergio Wolf (2001) acerca de la posibilidad de que el cine busque sus propias formas más allá de la analogía, desterrando la vieja idea de una jerarquía en la que la obra literaria debiera situarse en la cúspide de la pirámide frente a la posición subsidiaria del cine:

... más allá de las paráfrasis y analogías, lo que queda es siempre examinar el tipo de vínculos que se establecen entre las dos disciplinas. Y una primera condición esencial quizás sea comprender que el único modo de pensar la literatura y el cine es despojándolos de toda atribución positiva o negativa, extirpar la discusión de toda jerarquización entre origen y decadencia. (Wolf 2001: 29) 
Al acogerse al principio de un único código, la narrativa de Javier Marías integra la materia fílmica en un molde verbal, invalidando toda posible jerarquía. No hay un sistema binario de creación artística sino un texto impregnado de referencias cinematográficas en el que la imagen fílmica genera discurso narrativo, representación mental del personaje. Desde estas coordenadas no se ha de dirimir la superioridad estética del discurso verbal en detrimento de los medios visuales cuando las líneas de los distintos ejes de sentido convergen en la textualidad.

La pregunta que se plantea en este estudio estriba en formular de qué manera la textualidad o el discurso genera las imágenes: cuando no hay un doble código, la imagen fílmica se integra en el discurso verbal, en un decir sobre las imágenes. Aunque no haya codificación doble, tampoco es necesaria, como reconoce Mitchell: "No es necesario importar las representaciones visuales apropiadas para un discurso: estas son ya inmanentes a las palabras en el tejido de la descripción, la "visión" narrativa, los objetos y lugares representados, las metáforas" (2009: 91).

La representación verbal de una imagen visual (en este caso fílmica) se presenta como un "registro "visual de la escritura", como recientemente ha estudiado Topczewska (2016: 9) a propósito de la visualidad en 2666 de Roberto Bolaño. Cuando se desplaza el foco de análisis de las representaciones visuales (pinturas, fotografías, películas o dibujos) presentes en los textos hacia la visualidad integrada en la materia textual, esto es, el paso de dos códigos al código verbal único de una novela que integra distintos elementos cinematográficos fuente de discurso interior, el resultado es una obra de naturaleza híbrida. La hipótesis central, a este respecto, es que la visualidad inherente en el tejido verbal no siempre reproduce analógicamente las coordenadas del texto fílmico, sino que en muchos casos se distancia del modelo agrietando los fundamentos de la representación. Puesto que no siempre hay acuerdo entre lo que se dice verbalmente y lo que se muestra en términos visuales, las imágenes se refiguran continuamente, sometidas a un proceso metonímico y tropológico.

\subsection{Pluralidad: distintos cauces de expresión del fenómeno fílmico}

Debido a la imbricación del discurso fílmico-literario en un único código de naturaleza verbal -la novela-, aflora una pluralidad de formas de plasmación cinematográficas. Son plurales y distintos los cauces por los que la materia fílmica discurre en la escritura de Javier Marías: menciones explícitas, alusiones veladas, ambientación, mundos narrativos, obsesiones similares... Se podría establecer un continuum según el mayor o menor grado de irradiación de la materia fílmica sobre el texto literario, desde las menciones explícitas hasta las huellas veladas.

En este sentido, la cultura cinematográfica de Marías como un hecho familiar se trasfunde a sus personajes de ficción: espectadores de cine, espías furtivos, monologadores fantasmales cuya voz es resquicio del diálogo imposible entre vivos y muertos, observadores atentos de cuanto les rodea y, por extensión, personajes-cámara cuyos "ojos de la mente" (Marías 2013c: 320) persisten en la tarea de desvelar los múltiples resquicios interpretativos que quedan en la zona 
de sombra benetiana: "El cine, fundamentalmente norteamericano, [...] pese a todos los desdenes, estaba en la base de una cultura cinematográfica asimilada en la adolescencia" (Peña-Ardid 1991: 187).

Coexisten, por tanto, distintas vertientes para abordar esta relación fílmico-literaria. Destaca la presencia física del cine o bien de la televisión -con la llegada del telefilm- en que se emiten películas del Hollywood de los años cuarenta y cincuenta, como elemento intraficcional, de manera que los personajes de Marías se convierten en espectadores de cine, como sucede en Mañana en la batalla piensa en mí. En otros casos el punto de intersección se establece con la mención a películas que se sitúan como referente cultural de gran pujanza en el entramado de la ficción: en unos casos se evoca el título de forma directa y, en otros, se relatan ciertas peripecias del argumento que, a fortiori, permiten identificar la película a partir de huellas fílmicas como la mención a actores o a determinados espacios (Campanadas a medianoche de Orson Welles en Mañana en la batalla piensa en mí o Con la muerte en los talones de Hitchcock en Así empieza lo malo).

En la escritura de Marías es frecuente la caracterización y descripción de personajes novelescos a partir de rasgos físicos o psicológicos de actores de la cinematografía hollywoodiense (actores como Fred MacMurray en Recuerdo de una noche de Mitchell Leisen; Peter Lorre en $M$, el vampiro de Düsserldorf de Fritz Lang, tal como se menciona en Mañana en la batalla piensa en mí, o Jack Palance para caracterizar a Eduardo Muriel en Así empieza lo malo). Aunque son menos frecuentes, pueden rastrearse alusiones a dibujos animados (cartoon films) como muestra de la influencia que el visionado de estas películas en la infancia de los escritores tuvo para las ficciones literarias (es el caso de 101 dálmatas o Tintín en Mañana en la batalla piensa en mí; o en Tu rostro mañana o Todas las almas con el niño Eric, el hijo de Luisa, quien contempla una película en televisión...).

3.3. Superposición: de la vocación mimético-representativa al destello de la imagen-plano

Tras la reflexión ofrecida en estas páginas se puede argüir que el discurso fílmico en la narrativa de Marías no funciona a la manera de una adaptación cinematográfica de textos literarios. Al contrario, en su tratamiento impera una ruptura de la linealidad narrativa de modo que la imagen fílmica irrumpe sin atender a las cortapisas de la trama. Al igual que Marías se distancia de la vocación miméticorepresentativa de la novela de tradición decimonónica, acogiéndose a la estirpe literaria de Faulkner y Benet, la plasmación de la materia fílmica quiebra toda lógica de la linealidad para acoger un discurso interior de naturaleza reflexiva en el que la imagen imanta en su irrupción como un fulgurante destello. Como escribió Gubern (1987: 269), "cuando el espectador ve un film, no contempla una "historia" o un "argumento", sino imágenes móviles a partir de las cuales puede estructurar su conciencia". En esta línea interpretativa, cuando vemos una película en la pantalla no retenemos la totalidad de la historia sino momentos fílmicos de imágenes fulgurantes cuya carga simbólica se graba en la memo- 
ria. A este respecto, el dinamismo de la imagen fílmica sobre la pantalla se fija mentalmente y deviene lo que se va a denominar imagen-plano, fotograma funcional a la manera de un cuadro cuyo estatismo y fijeza le otorga una indeleble perpetuidad.

El marbete "imagen-plano" proviene de las ideas de Didi-Huberman (2011) a propósito de la "imagen-síntoma", la imagen que siempre vuelve como el síntoma freudiano que hace aflorar deseos latentes no resueltos. Este concepto posee una intensa capacidad explicativa para el tratamiento de lo fílmico en la obra de Marías. Aplicada la noción de síntoma a la hermenéutica de las imágenes, tal como estudió Imperiale (2016: 23) a propósito de la importancia de lo visual en la narrativa de Juan Benet, en la obra de Marías la imagen es rescatada de otro tiempo -fundamentalmente la cinematografía del Hollywood de los años cuarenta y cincuenta- como si se tratara de un "palimpsesto anacrónico" (Pittarello 2017: 365). La imagen-plano es allegada discursivamente y su ausencia icónica, por su inserción verbal en la novela, incentiva las figuraciones del narrador.

El fragmentarismo se produce en virtud de la captación de un momento fílmico, de un fotograma cualquiera que a modo de un pensamiento visual (Arnheim 1986) - de raigambre cinematográfica- se instaura como fuente germinativa del discurso interior. La importancia radica no tanto en la fidelidad a las películas evocadas, cuanto en el poder de la imagen para superponerse en distintos tiempos: el de la película (de Hitchcock, Mankiewicz o Welles) y el ahora de las novelas. Tiempos heterogéneos conviven en la reflexión verbal sobre la imagen-plano: tiempos que se solapan y se superponen, tiempos que conviven y se enfrentan, tiempos que pugnan y se abrazan en el eje sincrónico de la imagen. En este sentido, los narradores de Marías allegan verbalmente una imagen fílmica con un cierto anacronismo y superposición temporal, ${ }_{1}^{4}$ por lo que de forma dialéctica conviven y polemizan con el tiempo en que esa imagen se fraguó en la pantalla y el tiempo del "ahora" en que se asocia a la novela.

Refiriéndose a la "imagen-síntoma" acogida por Didi-Huberman a partir del "síntoma" freudiano y de la imagen dialéctica de W. Benjamin, escribió Pittarello en su lúcido estudio sobre los retratos de Marías en Negra espalda del tiempo: "Incompatible con la metafórica flecha de la cronología, la imagensíntoma obstaculiza el relato consecuencial del pasado introduciendo latencias anacrónicas en el vaivén sobredeterminado entre el saber y el sentir" (Pittarello 2017: 364). La posibilidad de cruzar distintos tiempos o de asimilar al contexto cultural del tiempo del relato los imaginarios fílmicos provenientes del cine de

\footnotetext{
${ }^{4}$ El carácter anacrónico y sobredeterminado de las imágenes en la narrativa de Javier Marías ha sido puesto de relieve por Elide Pittarello (2017: 365) a propósito de los retratos de familia en Negra espalda del tiempo. En las páginas de esta novela en que se narra la muerte, el narrador "inserta un retrato con funciones metonímicas, un dibujo de Helena Fourment, la segunda mujer y musa de Rubens: su propio retrato de familia. En un vertiginoso palimpsesto anacrónico, la joven retratada es el testimonio pictórico del adiós entre Javier Marías y su madre. Por su colocación tipográfica, aquí también el dibujo preside el recuerdo verbo-visual del escritor que se representa a sí mismo enseñándole a la madre agonizante la postal con el retrato de Helena Fourment" (Pittarello, 2017: 365). Valga la cita para justificar la importancia que la sobredeterminación temporal, la superposición de planos y el carácter fragmentario de las imágenes (ya sean fotográficas o fílmicas) adquiere en la narrativa de Marías.
} 
los años cuarenta y cincuenta, se manifiesta en virtud del carácter simultáneo de la mirada que, frente a la linealidad de la lectura, cruza tiempos diversos y opera de manera fragmentaria y sobredeterminada:

Mientras la lectura es lineal y ha de sujetarse al transcurso del tiempo, la mirada atraviesa simultáneamente varios momentos: el presente del fotografiado, el tiempo que transcurre desde el presente del fotografiado a su muerte, y el presente del espectador. La fotografía de alguien que ya no vive produce en el espectador un vértigo de perspectivas. (Cuñado 2004: 83-84)

A propósito de los pasajes de contemplación en distintas novelas de Marías Isabel Cuñado (2004: 84) dio cuenta del "vértigo de perspectivas" de la imagen contemplada o evocada mentalmente por el personaje. Frente a la linealidad de la palabra aflora la espiral interpretativa de la imagen o, en términos similares, se distingue el carácter progresivo de la palabra frente al simultáneo de la imagen, en virtud de la superposición de planos temporales dialogando e interactuando con el archivo visual.

La sugestión de la imagen como potencialidad sincrónica permite aunar distintos planos temporales en la mirada de quien contempla, en una nueva activación del presente al evocar una imagen fílmica. Este hecho resulta especialmente significativo en las escenas de contemplación en el museo Ashmolean de Oxford en Todas las almas, en los pasajes de espionaje furtivo de Jaime Deza en Tu rostro mañana y de Juan de Vere en Así empieza lo malo, ${ }^{5}$ evocadoras de imágenes de imperturbable estatismo y fijeza.

\section{CONCLUSIONES}

Quizá llamemos conclusiones a lo que aquí tan solo es tentativa de un final. En cualquier caso, y pese a las posibles vías que esta investigación abre hacia la reflexión teórica de la narrativa hispánica y sus hibridaciones fílmicas, a lo largo de estas páginas se ha sostenido la necesidad de superar el purismo disciplinar en que viven asfixiadas las disciplinas humanísticas para abrazar así el diálogo con otros lenguajes o códigos semióticos. Entre ellos se cuentan los provenientes de artes tan en auge como el cine.

A la luz de esta disquisición teórica y los problemas relativos a la traducción interlingüística y la imposible exactitud en el trasvase de códigos semióticos (verbales y visuales), se ha enfatizado el contraste entre el tratamiento de los documentos visuales (pictóricos o fotográficos) y la inserción de lo fílmico en el

\footnotetext{
${ }^{5}$ En el artículo "Reescribir el Vértigo (De entre los vivos): la impronta cinematográfica de Hitchcock en Así empieza lo malo, de Javier Marías", Carmen María López (2017) abordó la presencia del genio del suspense en la citada novela, incidiendo para ello en aspectos como la presencia de los detectives, la suplantación y el efecto de "lo siniestro" en los personajes femeninos, el patrón narrativo de la persecución y la ambientación y espacios hitchcockianos. Destaca, por lo tanto, la condición imitativa del personaje de Juan de Vere, quien continuamente asociará su comportamiento al de distintos actores -Cary Grant y James Stewart- cuyos rostros contempló en las películas de Hitchcock visionadas en la Filmoteca.
} 
tejido en la escritura. Esta condición bifurca el modo de relación de la literatura con otras artes en dos líneas emergentes: los lazos entre literatura y pintura, o literatura y fotografía devienen ejercicio intermedial por el doble código: verbal y visual, lingüístico e icónico.

A diferencia de ellos, el vínculo entre literatura y cine se presenta como una operación referencial, con el único código verbal como lenguaje hegemónico. Por ello, sostenemos aquí que Marías no muestra al lector fotogramas memorables de la historia del cine, sino que los refiere verbalmente integrándolos en el tejido narrativo. Tampoco los desarrolla de manera total ni fiel, sino que menciona y alude a momentos de la cinematografía del Hollywood de los años cuarenta y cincuenta. Sus referencias filmográficas - unas veces explícitas y otras veladas- se insertan de manera sucinta en la obra del autor, parco en palabras, puramente lacónico, como indicio fílmico de una microescena que crecerá en su sentido a lo largo de la pieza.

Como resultado de ellos, se han distinguido diversos criterios para abordar la presencia del cine en la narrativa de Javier Marías. En primer lugar, la verbalización, es decir, la representación verbal de la imagen integrada en el tejido narrativo; en una segunda orientación, la pluralidad o diverso tratamiento de la materia fílmica, desde las huellas veladas hasta las referencias explícitas a películas, directores y actores; en último término, la superposición o coincidencia temporal de dos imágenes (las de la película evocada y las del escenario en que se ambienta la obra) en el mismo eje sincrónico.

Esta singularidad de la imagen fílmica, más velada que revelada, más intuida que reproducida, otorga un tratamiento original a la relación cine-literatura en su obra, en claro contraste con la doble referencia verbal y visual en los casos de la pintura y la fotografía. La pluralidad de formas en que lo fílmico se integra en la escritura -sin acogerse a los cauces hegemónicos de las adaptaciones cinematográficas, de las versiones o de influencias declaradas-reclama una atención y estudio minucioso. Quizá este silencio de la imagen fílmica, apenas referida verbalmente como impulso visual de la escritura, haya motivado el descuido por parte de la crítica. Quizá a partir de ahora sea preciso abordar su tratamiento.

\section{OBRAS CITADAS}

Agudelo, Pedro Antonio (2011): "Los ojos de la palabra. La construcción del concepto de écfrasis, de la retórica antigua a la crítica literaria", Lingüística y Literatura, vol. 1, n. ${ }^{\circ} 60$, pp. $75-92$.

Arnheim, Rudolf (1986): El pensamiento visual. Barcelona, Paidós.

Bazin, André (2006): ¿Qué es el cine? Madrid, Rialp.

Belting, Hans (2012): Antropología de la imagen. Buenos Aires/Madrid, Katz.

Candeloro, Antonio (2008): "Visiones transversales: los documentos visuales en algunas novelas contemporáneas". En: Actas del xv Simposio Internacional sobre Narrativa Hispánica Contemporánea. El Puerto de Santa María, 24, 25 y 26 de noviembre de 2007. Puerto de Santa María, Fundación Luis Goytisolo, pp. 53-56. 
— (2016): Javier Marías y el enigma del tiempo. Murcia, Universidad de Murcia.

Cuñado, Isabel (2004): El espectro de la herencia. La narrativa de Javier Marías. Amsterdam/ Nueva York, Rodopi.

Didi-Huberman, Georges (2011): Ante el tiempo. Historia del arte y anacronismo de las imágenes. Buenos Aires, Adriana Hidalgo editora.

Faro Forteza, Agustín (2006): Películas de libros. Zaragoza, Prensas universitarias.

Genette, Gerard (1989): Figuras III. Barcelona, Lumen.

Gimferrer, Pere (1985): Cine y literatura. Barcelona, Planeta.

Company, Juan Manuel (1987): El trazo de la letra en la imagen. Texto literario y texto fílmico. Madrid, Cátedra.

Peña-Ardid, Carmen (1992): Literatura y cine. Una aproximación comparativa. Madrid, Cátedra.

González de Ávila (2010a): Cultura y razón. Antropología de la literatura y de la imagen. Barcelona, Anthropos.

González de Ávila, Manuel (2010b): "El arte y el cine, entre transcripción y reescritura (Por una semiótica transversal)". En José Antonio Pérez Bowie (ed.): Reescrituras fílmicas: nuevos territorios de la adaptación. Salamanca, Ediciones Universidad de Salamanca, pp. 103-117.

Gubern, Roman (1987): La mirada opulenta. Exploración de la iconosfera contemporánea. Barcelona, Editorial Gustavo Gilli.

Hefferman (1993): Museum of Words. Poetics of Ekphrasis from Homer to Ashbery. Chicago, Chicago University Press.

Imperiale, Stefania (2016): Contar por imágenes: la narrativa de Juan Benet. Sevilla, Renacimiento.

Jakobson, Roman (1959): "On Linguistic Aspects of Translation". En Reuben Arthur Brower (ed.): On Translation. Cambridge, Harvard University Press, pp. 232-239.

Jakobson, Roman (1981): Ensayos de Lingüística general. Barcelona, Ariel.

Kawin, Bruce (1978): Mindscreen. Bergman, Godard and first person film. Princeton, Nueva Jersey, Princeton University Press.

Lessing, Gotthold Ephraim (1985): Laocoonte o sobre los límites en la pintura y la poesía. Barcelona, Orbis.

Logie, Ilse (2001): "La traducción, emblema de la obra de Javier Marías". En Maarten Steenmeijer (ed.): El pensamiento literario de Javier Marías. Amsterdam/Nueva York, Rodopi, pp. 67-76.

López-Gay, Patricia (2013): Archivo y ficción. Javier Marías, Enrique Vila-Matas: Miradas sobre el mundo y su tiempo. Tesis doctoral inédita. Universidad de Nueva York.

López López, Carmen María (2015): "El cine como clave cultural y hermenéutica en la narrativa de Javier Marías: una lectura de Así empieza lo malo". En Fidel López Criado (ed.): La diversidad en la literatura, el cine y la prensa española contemporánea. Santiago de Compostela, Andavira, pp. 287-294.

- (2017): "Reescribir el Vértigo (De entre los vivos): la impronta cinematográfica de Hitchcock en Así empieza lo malo, de Javier Marías", Signa. Revista de la Asociación Española de Semiótica, vol. 1, n. ${ }^{\circ} 26$, pp. 269-290.

- (2018): "Películas sin voz y otros insomnios: Claves fílmicas en Mañana en la batalla piensa en mí, de Javier Marías". En David García Ponce, Laura Pache Carballo y Chris- 
tian Snoey Abadías (eds.): El texto de las mil caras. Hibridismo y nuevas tendencias en la literatura española e hispanoamericana. Sevilla, Renacimiento, pp. 283-297.

_ (2019): El cine en el pensamiento y la creación de Javier Marías. Vigo, Editorial Academia del Hispanismo.

Marías, Javier (1993): Literatura y fantasma. Madrid, Siruela.

— (1995): Vida del fantasma. Madrid, Alfaguara.

- (1997): Mañana en la batalla piensa en mí. Madrid, Alfaguara.

- (1999): Los dominios del lobo. Madrid, Alfaguara.

- (2000): Salvajes y sentimentales. Letras de fútbol (2000). Madrid, Aguilar.

- (2002): Tu rostro mañana I. Fiebre y lanza. Madrid, Alfaguara.

- (2005a): Tu rostro mañana II. Baile y sueño. Madrid, Alfaguara.

- (2005b): Donde todo ha sucedido. Al salir del cine. Barcelona, Galaxia Gutenberg.

— (2007): Tu rostro mañana III. Veneno y sombra y adiós. Madrid, Alfaguara.

_ (2013a): Negra espalda del tiempo. Barcelona, De Bolsillo.

- (2013b): Todas las almas. Barcelona, De Bolsillo.

— (2013c): Tu rostro mañana. Barcelona, De Bolsillo.

— (2014): Así empieza lo malo. Barcelona, Alfaguara.

Martín-Estudillo, Luis (2009): "Del pensamiento visual al pensamiento literario". En Alexis Grohmann y Maarten Steenmeijer (eds.): Allí donde uno diría que ya no puede haber nada. Tu rostro mañana de Javier Marías. Amsterdam/Nueva York, Rodopi, pp. 115-132.

Miller, Stephen (2004): "Graphic-lexical Dialogue in Marías and Rivas", Romance Quarterly, vol. 1, n. ${ }^{\circ}$ 51, pp. 97-110.

Mitchell, William (2009): Teoría de la imagen. Ensayos sobre representación verbal y visual. Madrid, AKAL.

Mora, Vicente Luis (2012): El lectoespectador: deslizamientos entre literatura e imagen. Barcelona, Seix Barral.

Pérez-Carbonell, Marta (2016): The Fictional World of Javier Marías. Language and Uncertainty. Leiden/Boston, Brill/Rodopi.

— (2017): "Compulsive Translators: Are Narrators in Javier Marías's Novels Beguiled by Language?", Hispanic Research Journal, vol. 18, n. ${ }^{\circ}$, pp. 338-351.

Pimentel, Luz Aurora (2003): "Écfrasis y lecturas iconotextuales", Poligrafías IV, 205-215.

Pittarello, Elide (2017): "Retratos de familia en Negra espalda del tiempo de Javier Marías". En Natalie Noyaret y Anne Paoli (eds.): L'écrivain à l'œuvre dans le récit de fiction espagnol contemporain. Binge, Éditions Orbis Tertius, pp. 353-366.

Pozuelo Yvancos, José María (2010): Figuraciones del yo en la narrativa: Javier Marías y E. Vila-Matas. Valladolid, Cátedra Miguel Delibes.

- (2017): Novela española del siglo xxı. Madrid, Cátedra.

Sánchez Noriega, José Luis (2000): De la literatura al cine. Teoría y análisis de la adaptación. Barcelona, Paidós.

Scarlett, Elizabeth (2004): "Victors, Villains and Ghosts: Filmic Intertextuality in Javier Marías's Mañana en la batalla piensa en mí", Revista Canadiense de Estudios Hispánicos, vol. 1, n. ${ }^{\circ}$ XxvIII, pp. 391-410.

Scharm, Heike (2013): El tiempo y el ser en Javier Marías: el Ciclo de Oxford a la luz de Bergson y Heidegger. Amsterdam/Nueva York, Rodopi. 
Segre, Cesare (1985): Principios de análisis del texto literario. Barcelona, Crítica.

Steenmeijer, Maarten (2001): El pensamiento literario de Javier Marías. Amsterdam/Nueva York, Rodopi.

Topczewska, A. (2016): "Sin título. Operaciones de lo visual en 2666 de Robert Bolaño", Études romanes de Lund, n. ${ }^{\circ} 104$.

Utrera, Rafael (1985): Escritores y cinema en España: un acercamiento histórico. Madrid, Ediciones JC.

Wagner (1996): Icons and Iconotexts: Essays on Ekphrasis and Intermediality. Nueva York, de Gruyter.

Wolf, Sergio (2001): Cine/Literatura. Ritos de pasajes. Buenos Aires, Paidós.

\section{FiLMOgRAFÍA}

Hitchcock, Alfred (1958): Vértigo (De entre los muertos). Estados Unidos, Paramount Pictures.

- (1959): Con la muerte en los talones (North by Northwest). Estados Unidos, MetroGoldwyn-Mayer.

Lang, Fritz (1931): M, El vampiro de Düsseldorf. Alemania, Nero Film.

Leisen, Mitchell (1940): Recuerdo de una noche (Remember the Night). Estados Unidos, Paramount Pictures.

Mankiewicz, Joseph L. (1947): El fantasma y la señora Muir (The Ghost and Mrs. Muir). Estados Unidos, 20th Century Fox.

Renoir, Jean (1951): El río (Le fleuve). Francia, Theter Guild / Oriental International Film.

Welles, Orson (1965): Campanadas a medianoche (Falstaff - Chimes at Midnight). España, Alpine Films / Internacional Films. 